\title{
Contrast Enhancement Using Curd and Contrast Agent Mixtures for Ex Vivo Vessel Imaging in Com- puted Tomography
}

\section{Kontrastanhebung mit einer Mischung aus Quark und Kontrastmittel für computertomografische ex vivo Gefäßdarstellungen}

\section{Zusammenfassung \\ $\nabla$}

Wir beschreiben eine preisgünstige und effiziente Methode, um den VaskularRaum von ex vivo Gewebeproben mit einem röntgendichten Material auszufüllen, dass in der computertomografischen Bildgebung angewendet werden kann. Das Füllmaterial besteht aus Quark, Wasser und einem Röntgenkontrastmittel. Viskositätsbereiche und der Grad an Röntgenstrahlenabsorption des Füllmaterials lassen sich leicht an spezielle Anforderungen anpassen. Die Methode ist zerstörungsfrei und hat keine negativen Einflüsse auf nachfolgende histologische Untersuchungen.

\section{Introduction \\ $\nabla$}

We report how to prepare a cheap radiopaque filling material that sounds at first like a curiosity. The imaging optimizations were developed especially to investigate forensic tissue samples. Postmortem imaging of organs or tissue fragments has become increasingly important for the evaluation of the cause of death and possible comorbidity under circumstances that may be very specific ([1] Grabherr $S$ et al. Am J Radiol 2007; 188: 832 -838). Here, our contrast medium proved its functionality perfectly in postmortem computed tomography of the vascular system.

Standard ex vivo $\mathrm{CT}$ imaging techniques of blood vessels use the Microfil ${ }^{\circledR}$ product line, offered by FlowTech, Carver, Massachusetts, USA. FlowTech products enable the preparation of beautiful, long lasting casts with a huge benefit in research and teaching. Radiopaque Microfil products enhance the contrast of the filled spaces encapsulated by tissue of generally lower attenuation of X-rays, hence enabling CT imaging. Thus, standard histological cutting methods are not performable when the vascular system is filled with a plas-

\section{Abstract \\ $\nabla$}

We describe a cheap and efficient method for filling the vascular space of ex vivo tissue samples with a radiopaque material that can be used in computed tomography imaging. The filling material consists of curd, water, and a radiological contrast agent. Viscosity ranges and the degree of attenuation of X-rays of the filling material can be easily adjusted to the requirements of a specific application. The method is non-destructive and without negative effects on subsequent histological examinations.

tic-like material. Therefore, we needed a radiopaque filling material that enabled filling of a vessel system with minimal effect so that a CT scan would image the original condition of the tissue of an organ. This implies especially that the filling material has to be within a wide adjustable viscosity range so that injections into the tissue samples are readily possible. The material should be easy to handle, easy to prepare, and cheap, and contain no harmful materials. Furthermore, it must be possible to perform histological examinations of the forensic tissue directly after a CT scan. A radiopaque filling material containing curd, clinical contrast agent, and water fulfilled all these desired requirements.

\section{Materials, Methods, and Results $\nabla$}

- Fig. 1 shows the experimental setup of the injection of the curd-contrast-agent mixture under physiological pressure conditions on the scanner table. The CT investigation was performed with a flatpanel-based eXplore Locus Ultra ${ }^{\circledR}, \mathrm{GE}$ Healthcare, London, Ontario, Canada. 640

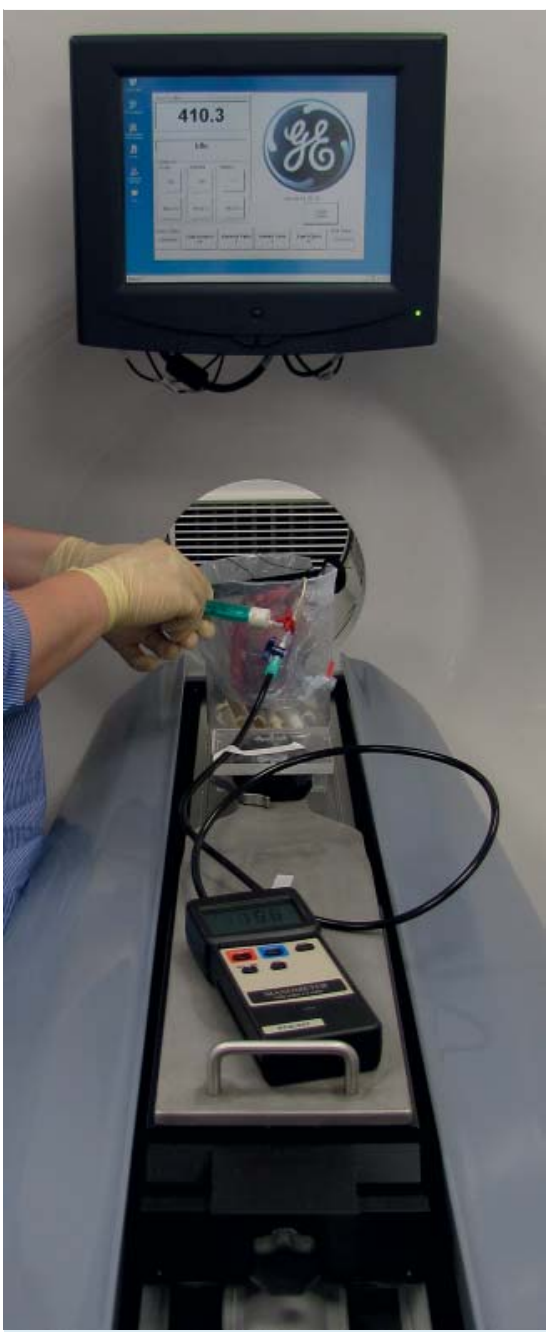

Fig. 1 Setup of the radiological investigation of a forensic sample. The hands, shown on the left of the photograph, inject the curd-contrast-agent-water mixture. A syringe, a pressure gauge (image foreground), and a catheter (image background), which goes to the vessel of the tissue sample under investigation, are connected by a three-way cock. After the injection of the contrast agent mixture, the three-way cock is closed in the direction of the tissue sample.

Abb. 1 Aufbau zur radiologischen Untersuchung eines Weichteilpräparates aus der Rechtsmedizin. Die Hände links im Bild applizieren das Kontrastmittelgemisch aus Quark, Röntgenkontrastmittel und Wasser. Über einen Dreiwegehahn (im Bildzentrum) sind eine Spritze, ein Manometer (Bildvordergrund) und ein Katheter (Bildhintergrund) zum Zugangsgefäß des zu untersuchenden Präparates angeschlossen. Nach der Verabreichung des Kontrastmittelgemisches wird der Dreiwegehahn zur Gewebeprobe hin verschlossen.

rows and 1024 columns were read out from the detector in the used protocol. 1000 views were taken in one gantry rotation of $16 \mathrm{~s}$ duration at $140 \mathrm{kVp}$ and $10 \mathrm{~mA}$. The CT data were reconstructed 
with a cone-beam filtered back-projection algorithm into a $512 \times 512 \times 340$ voxel matrix. The 12-bit DICOM image data had isotropic voxel sizes of $(0.295 \mathrm{~mm})^{3}$. - Fig. 2 shows an image of the coronary vessels of a human heart under investigation in the forensic department. Fig. 3 shows a detailed view of the micro-vascularization. Visualization of the data was performed with an Advantage Worksta$\operatorname{tion}^{\circledR}$, Version 4.1, GE Medical Systems, Buc, France. Vessel filling and contrast enhancement were achieved using a curdcontrast-agent mixture. $\bullet$ Fig. 4 shows a histological image of a sample of an organ that received vascular filling with the curd-contrast-agent mixture and underwent a subsequent CT scan prior to histo-

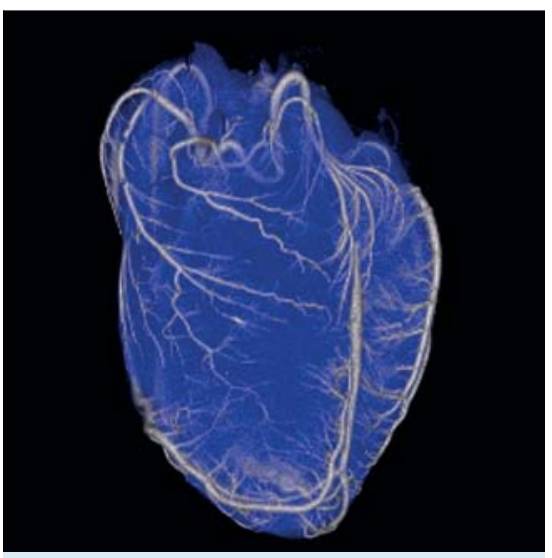

Fig. 2 Volume rendering image of the coronary arteries of a human heart. Image bottom border length is $13.0 \mathrm{~cm}$.

Abb. 2 Volumen-Rendering-Darstellung der Herzkranzgefäße eines menschlichen Herzens. Die untere Bildkante ist $13,0 \mathrm{~cm}$ lang.

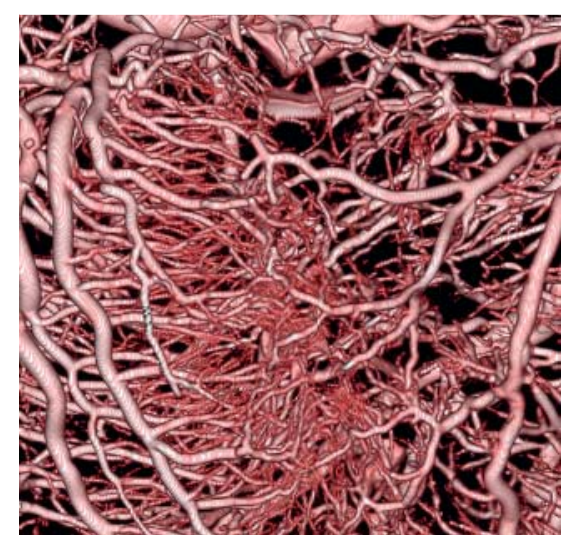

Fig. 3 Detail view of a heart's microvascular system. Image bottom border length is $5.5 \mathrm{~cm}$.

Abb. 3 Detailansicht der Mikrovaskularisation eines Herzens. Untere Bildkantenlänge ist $5,5 \mathrm{~cm}$. logical analysis. The histological examinations showed that no curd-contrast-agent could be found in the extravasal space.

To prepare the curd-contrast-agent mixture, we used low-fat curd (Ehrmann AG, Oberschönegg, Germany), and Micropaque $^{\circledR}$ CT suspension (Guerbet, Sulzbach, Germany) as the contrast agent. A typical mixture contains e.g. $35 \mathrm{ml}$ curd, $12 \mathrm{ml}$ Micropaque CT suspension, and $6 \mathrm{ml}$ water. The mixture must be thoroughly shaken. Air bubbles have to be removed by vacuum, or by other appropriate methods. An option to perform this is to put the contrast media mixture in a flask that is connected via a three-way cook to a water-jet vacuum pump or another vacuum source. Application of vacuum for a duration of $30 \mathrm{~s}$ is sufficient. When the vacuum is shut off, the contrast media mixture must be slowly brought back to normal air pressure by slowly opening the threeway cook. There may not be any air bubbles in the mixture that is finally injected. It is recommended to check the optimal amount of the different components of the recipe in pre-evaluations with animal organs. High curd concentrations lead to mixtures with high viscosities that can hardly be injected. Variations of the viscosity may be tried out by changing the water concentration in a range from 10 to $20 \mathrm{ml}$ - referring to the amounts of the different components mentioned above. High concentrations of contrast agent

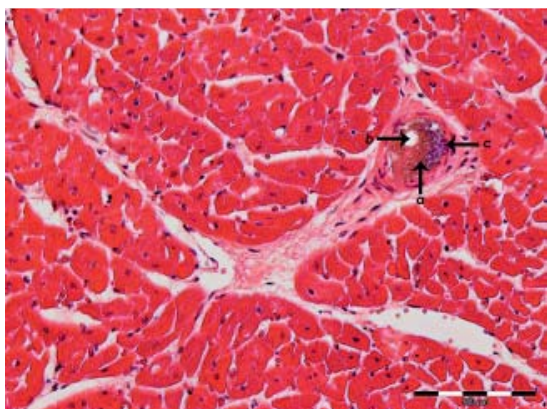

Fig. 4 Histological image of hematoxylin eosin staining of heart muscle tissue after the application of the contrast media mixture. Within the tissue, an arteriole is visible containing a contrast medium, b empty residual lumen, and c erythrocytes. The histological examination is not affected by the contrast media injection.

Abb. 4 Histologisches Bild einer Hematoxylin-Eosin-Färbung von Herzmuskelgewebe nach der Anwendung der Kontrastmittelmischung. Innerhalb des Gewebes ist eine Arteriole sichtbar, die a Kontrastmittel, b leeres Residual-Lumen und c Erythrozyten enthält. Die histologische Untersuchung wird nicht durch die Kontrastmittelinjektion beeinträchtigt. may lead to beam hardening artifacts in CT imaging. Low concentrations may produce only insufficient contrast enhancement. Variations concerning the radiopaque imaging properties of the contrast media mixture may be evaluated in a range from 10 to $20 \mathrm{ml}$ of the Micropaque CT suspension.

\section{Discussion \\ $\nabla$}

In this study we introduced a contrast agent mixture and we showed CT imaging results in 0 Fig. 2, 3 from the area of forensic medicine. A general introduction into the peculiarities of postmortem imaging of human cadavers is given in the review article in ref. [1]. Those authors show e.g. that there was always an astonishing amount of imagination concerning the materials being used to prepare vessel casts or to produce radiopaque contrast media for X-ray-based vessel imaging. Currently used post mortem angiography materials include diesel or paraffin oil with an addition of a lipophilic contrast agent (Grabherr S et al. Am J Radiol 2006; 187:W515-W523). Grabherr and coworkers developed and standardized a post mortem angiographic method where a modified heart lung machine is used to establish an artificial paraffin circulation in a complete human cadaver. A bolus injection of an oily contrast agent can then be used to conduct an angiography investigation comparable to an angiography performed in living subjects (Grabherr S et al. Int J Legal Med 2011; 125: 791 -802). Such angiography methods are possible in cadavers up to three days post mortem. Decomposition of the tissue and the heterogeneous variation of the tissue stiffness after that make standardization difficult or impossible. The controversy described in ref. [1] concerning the injection methods, which range from manual injections to pressure controlled pumps, or gravity, is therefore easy to understand. These issues must be seen in the background of the basic challenge in forensic medicine not to alter an exam result by the investigation method. Minimal invasiveness is therefore important and it is strongly recommended to handle a subject or an organ as carefully as possible.

We conclude that there is no general optimal composition of the different components of the contrast media mixture. Organs such as the heart, liver or kidneys can be rather stiff, rigid, and hard, or they 
can be soft, mellow, or flexible in forensic investigations, depending on the cause and circumstances of death, storage of specimen, and time of postmortem imaging. Therefore, it is not easy to obtain reproducible vascular fillings that give a similar visual result. Manometer control to gain a reproducible injection pressure is only sometimes helpful, since organ conditions can vary substantially. A certain degree of expertise is necessary to obtain acceptable results, which is independent of the filling material used. We assume that this methodology can also be applied successfully in experimental radiology, small animal imaging, and general preclinical investigations. The standard method of vessel investigations from isolated organs is in this area rather based on $\mathrm{Mi}-$ crofil preparations. Typical applications are the morphometrical analysis of the branching angles of porcine coronary arterial tree from CT images by Wischgold and colleagues (Wischgoll T et al. Am J Physiol Heart Circ Physiol 2009; 297: H1949 - H1955), the quantitative ex-vivo micro-computed tomographic imaging of blood vessels and necrotic regions within tumors by Downey and coauthors (Downey CM et al. PLoS ONE 2012; 7: e41 685), or the quantification of the vasa vasorum density in MSCT coronary angiograms by Moritz and colleagues (Moritz R et al. J Comput Assist Tomogr 2010; 34: 273 278). Such plastic cast producing methods have some disadvantages compared to the suggested "curd-method": plastic material may shrink minimally during the harden- ing process; higher costs; and furthermore the difficulties to perform histological examinations when a hard plastic material is embedded in the tissue. A basic advantage of the use of plastic materials is the resulting cast, which can be used to conduct anatomic measurements or visual presentations. Thus, current developments in information technology make such casts often needless since anatomic measurements can be performed on digital CT data. Similarly, the digital presentation of CT data is currently standard and $3 \mathrm{D}$ printing is also an option if casts are necessarily used.

M. Obert, L.M. Kohl, N. Graf, G.A. Krombach, M.A. Verhoff, Giessen 